\title{
A PCR technique based on the Hip1 interspersed repetitive sequence distinguishes cyanobacterial species and strains
}

\author{
J. K. Smith, ${ }^{1}$ J. D. Parry, ${ }^{1}$ J. G. Day ${ }^{2}$ and R. J. Smith ${ }^{1}$
}

\author{
Author for correspondence: R. J. Smith. Tel: +44 152465201 ext. 93515 . Fax: +441524843854. \\ e-mail : r.smith@lancaster.ac.uk
}

1 IENS, Division of Biological Sciences, Lancaster University, Bailrigg, Lancaster LA1 4YQ, UK

2 Culture Collection of Algae and Protozoa (CCAP), IFE, Windermere Laboratory, The Ferry House, Far Sawrey, Ambleside, Cumbria LA22 OLP, UK

\begin{abstract}
The use of primers based on the Hip1 sequence as a typing technique for cyanobacteria has been investigated. The discovery of short repetitive sequence structures in bacterial DNA during the last decade has led to the development of PCR-based methods for typing, i.e. distinguishing and identifying, bacterial species and strains. An octameric palindromic sequence known as Hip1 has been shown to be present in the chromosomal DNA of many species of cyanobacteria as a highly repetitious interspersed sequence. PCR primers were constructed that extended the Hip1 sequence at the $3^{\prime}$ end by two bases. Five of the 16 possible extended primers were tested. Each of the five primers produced a different set of products when used to prime PCR from cyanobacterial genomic DNA. Each primer produced a distinct set of products for each of the 15 cyanobacterial species tested. The ability of Hip1based PCR to resolve taxonomic differences was assessed by analysis of independent isolates of Anabaena flos-aquae and Nostoc ellipsosporum obtained from the CCAP (Culture Collection of Algae and Protozoa, IFE, Cumbria, UK). A PCR-based RFLP analysis of products amplified from the 235-16S rDNA intergenic region was used to characterize the isolates and to compare with the Hip1 typing data. The RFLP and Hip1 typing yielded similar results and both techniques were able to distinguish different strains. On the basis of these results it is suggested that the Hip1 PCR technique may assist in distinguishing cyanobacterial species and strains.
\end{abstract}

Keywords: cyanobacteria, typing, identification, Hip1, repetitive sequence primed PCR

\section{INTRODUCTION}

The ability to distinguish species and strains of bacteria is essential for environmental and epidemiological studies. In recent years molecular genetic techniques have been developed to supplement or supplant conventional methods that are based on techniques such as immunological (serotyping) and bacteriophage-susceptibility characteristics (Tenover $e$ t al., 1995). The newer molecular genetic techniques all seek to detect differences in DNA sequence structure present either in the chromosomal DNA of a species or in a contained plasmid. One common approach assesses differences, often in the presence of restriction endonuclease sites, that are present in a small segment of the genome such

Abbreviations: ITS, internal transcribed spacer; RAPD, randomly amplified polymorphic DNA; STRR, short tandemly repetitive repeat. as a particular gene. Methods based on the intergenic regions within the rRNA cistrons (rDNA sequencing and ribotyping) have been particularly popular (Stull $e t$ al., 1988; Vila et al., 1996). Another, well-regarded technique assesses RFLPs generated by restriction of chromosomal DNA with rare-cutting restriction endonucleases and the use of pulsed-field gel electrophoresis to separate the fragments (Arbeit et al., 1990; Frey et al., 1996; Le-Bourgeois et al., 1993).

A third method employs the PCR reaction to show differences between species by analysing the size of the DNA products amplified from a genomic DNA template by a variety of primers. In higher organisms (Welsh $\&$ McClelland, 1990), sets of random primers have been used to generate randomly amplified polymorphic DNA (RAPD)-PCR products, which produce banding patterns, when separated on agarose gels, that are characteristic of species and even individual organisms. 
The minimum size of a primer which is capable of specific interaction with a DNA sequence (10-12 bp) and the much smaller size of the bacterial genome as compared to that of higher organisms limit the general application of RAPD techniques to bacteria, although several RAPD-PCR techniques for distinguishing bacteria have been described (Lipman et al., 1996; Mahenthiralingam et al., 1996; Schmidt et al., 1991). Similar techniques have been developed that are based on primers designed to hybridize with repeated sequence structures present in bacterial DNA. The primers permit amplification of the DNA sequences between those adjacent repeated sequences which are present in a suitable orientation and distance apart. A number of different examples of the technique have been published, including ERIC (Enterobacterial Repetitive Interspersed Consensus) (Hulton et al., 1991) and REP (Repetitive Extragenic Palindrome) (Versalovic et al., 1991; Giesendorf et al., 1993; Georghiou et al., 1995).

Classically the distinguishing of different species of cyanobacteria has relied essentially upon identifying morphological and developmental characteristics by light microscopy (Rippka, 1988; Castenholz et al., 1992). Considerable expertise is required to identify species since both morphological and developmental characteristics can vary with the growth conditions (Evans et al., 1976; Doers \& Parker, 1988). In some instances it is not too difficult to identify cyanobacterial isolates to the genus level, particularly where morphological characteristics are significantly different from most other genera, e.g. Calothrix. However, for many genera, including Oscillatoria, Lyngbya and Phormidium, it is often difficult for the non-expert to be confident of their diagnosis. The problems of identification increase further at the species level and little is known about subspecies variation, i.e. strains.

Although they would be useful in distinguishing cyanobacterial isolates and in maintaining laboratory and collection cultures, only a few molecular genetic techniques for typing cyanobacteria have been developed. The cloning and sequencing of rRNA cistrons has most frequently been used to identify cyanobacteria in environmental samples and to investigate phylogeny (Britschgi \& Giovannoni, 1991; Ferris et al., 1996; Fuhrman et al., 1993; Nelissen et al., 1994; Neilan, 1996; Schmidt et al., 1991). Lotti et al. (1996) used the restriction endonucleases $B f a \mathrm{I}$ and $H p a \mathrm{I}$ to create unique RFLP banding patterns of chromosomal DNA to distinguish symbiotic Nostoc isolates. Neilan et al. (1995) found RFLPs, in PCR-amplified products of the phycocyanin gene, that distinguished between toxic Microcystis and Anabaena strains. Neilan (1996) reported the use of a RAPD technique to distinguish Anabaena and Microcystis isolates responsible for producing nuisance blooms in freshwater.

Filamentous heterocystous cyanobacteria contain STRR (short tandemly repetitive repeat) sequences (Mazel $e t$ al., 1990) and LTRR (long tandemly repetitive repeat) sequences, that have been used as Southern blot RFLP hybridization probes (Rouhiainen et al., 1995) and PCR typing (Rasmussen \& Svenning, 1998) to distinguish cyanobacteria. Another interspersed repeated sequence known to be common to many, but not all, cyanobacterial species is an $8 \mathrm{bp}$, highly iterated palindromic sequence known as Hip1 (Gupta et al., 1993). Robinson et al. (1995) have shown that the use of Hip1 as a primer in PCR amplification from genomic DNA generated product banding patterns that were characteristic of species. However, large numbers of products are generated with some species, producing complex banding patterns. We demonstrate here that DNA amplification from cyanobacterial DNA templates using primers based on the Hip1 sequence, but extended by an additional two bases at the $3^{\prime}$ end, yields reproducible banding patterns that distinguish different species and isolates (strains) of cyanobacteria.

\section{METHODS}

Cyanobacteria and culture conditions. A range of cyanobacteria (Table 1), maintained in the CCAP collection (http: //www.ife.ac.uk/ccap/) and varying in morphology from simple unicells to forms with branched filaments, heterocysts and akinetes, were examined in this study. Species cultured in JM medium or BG11 medium (Tompkins et al., 1995) were grown under 'environmental' conditions $\left(15^{\circ} \mathrm{C}\right.$, a 12:12 h light : dark cycle, irradiance $\left.25 \mu \mathrm{mol} \mathrm{m}{ }^{-2} \mathrm{~s}^{-1}\right)$. Species cultured in AA/4 medium (Allen \& Arnon, 1955) were grown at $29^{\circ} \mathrm{C}$ under a $24 \mathrm{~h}$ light regime $\left(30 \mu \mathrm{mol} \mathrm{m} \mathrm{m}^{-2} \mathrm{~s}^{-1}\right)$. Isolates used to assess the resolution of subspecific differences are listed in Table 2.

Exponential or early stationary phase cultures $(10 \mathrm{ml})$ were harvested by centrifugation ( 3500 r.p.m., $10 \mathrm{~min}$ ) and washed twice in the appropriate sterile medium and/or twice in sterile TE buffer ( $10 \mathrm{mM}$ Tris/ $\mathrm{HCl}, \mathrm{pH} 7 \cdot 2,1.0 \mathrm{mM}$ EDTA), with a final resuspension in $750 \mu \mathrm{l}$ TLES buffer $(50 \mathrm{mM}$ Tris $/ \mathrm{HCl}$, pH 9.5, $150 \mathrm{mM} \mathrm{LiCl,} 5 \mathrm{mM}$ EDTA, 5\% SDS).

DNA isolation. The resuspended material was added to a screw-capped Eppendorf tube filled with glass microbeads (acid washed, $425-600 \mathrm{~nm}$, Sigma) to the $500 \mu \mathrm{l}$ mark. The tubes were attached by screw clamps to a Griffin flask shaker and shaken at maximum revolutions (approximately 300 r.p.m.) for $7 \mathrm{~min}$ to break open cells. The release of phycoerythrin and phycocyanin pigments from some species allowed cell breakage to be monitored by eye. Cell debris was removed by centrifugation in a microfuge (13200 r.p.m., $8 \mathrm{~min})$. The supernatant was removed to a fresh tube containing an equal volume $(500 \mu \mathrm{l})$ of phenol/chloroform/ isoamyl alcohol (25:24:1, by vol.; Sigma) and mechanically mixed for $1 \mathrm{~min}$ followed by centrifugation (microfuge, 13200 r.p.m., $15 \mathrm{~min}$ ) and removal of aqueous supernatant to a fresh tube. The phenol/chloroform/isoamyl alcohol extraction was repeated. A full $15 \mathrm{~min}$ centrifugation for both extractions decreased protein and polysaccharide contamination of the final product.

A one-tenth volume $(50 \mu \mathrm{l})$ of $5 \mathrm{M}$ potassium acetate $(3 \mathrm{M}$ potassium acetate in $2 \mathrm{M}$ acetic acid) was added to the supernatant. The sample was placed on ice for $10 \mathrm{~min}$, during which time a turbid suspension appeared in some samples. This suspension was pelleted by centrifugation (microfuge, 13200 r.p.m., $15 \mathrm{~min}$ ) and the supernatant retained. Two volumes $(1 \mathrm{ml})$ of absolute ethanol were added and the sample 
Table 1. Test species of cyanobacteria

\begin{tabular}{|lll|}
\hline Species & \multicolumn{1}{|c|}{ Isolate identification } & Medium \\
\hline Anabaena cylindrica & CCAP 1403/2a & JM \\
Oscillatoria amoena & CCAP 1459/39 & JM \\
Calothrix sp. & CCAP 1429/1 & BG11 \\
Nostoc flagelliforme & CCAP 1553/33 & BG11 \\
Anabaenopsis circularis & CCAP 1402/1 & BG11 \\
Fischerella muscicola & CCAP 1427/1 & BG11 \\
Symploca muscorum & CCAP 1478/1 & BG11 \\
Synechocystis sp. & CCAP 1480/4 & BG11 \\
Nostoc muscorum & CCAP 1453/20 & BG11 \\
Anabaena sp. & CCAP 1446/1C & BG11 \\
Anabaena flos-aquae & CCAP 1403/13A, /13B, /13D to /13H & BG11 \\
Nostoc ellipsosporum & CCAP 1453/2,/11,/15 to /19 & BG11 \\
Anabaena & ATCC 27892 & AA/4 \\
Anabaena & PCC 7120 & AA/4 \\
Nostoc Mac R1 & P. Bisen (Barkatullah University, India) & AA/4 \\
\hline
\end{tabular}

Table 2. Isolates used to assess resolution of subspecific differences

See the CCAP on-line database [http://www.ife.ac.uk/ccap/] for further information on these strains.

\begin{tabular}{|c|c|c|}
\hline Species & Isolate identification & $\begin{array}{c}\text { Origin, year of isolation and other } \\
\text { characteristics }\end{array}$ \\
\hline Anabaena sp.* & CCAP $1403 / 13 A$ & $\begin{array}{l}\text { Sewage oxidation pond, Mississippi, } \\
\text { USA; } 1964\end{array}$ \\
\hline Anabaena flos-aquae & CCAP $1403 / 13 B$ & Windermere, Cumbria, England; 1964 \\
\hline Anabaena flos-aquae & CCAP $1403 / 13 \mathrm{C}$ & Blelham Tarn, Cumbria, England; 1972 \\
\hline Anabaena flos-aquae & CCAP $1403 / 13 D$ & Wales; 1976 ; mutant, no gas vacuoles \\
\hline Anabaena flos-aquae & CCAP $1403 / 13 E$ & Wales; 1976 ; mutant, helical filaments \\
\hline Anabaena flos-aquae & CCAP $1403 / 13 F$ & $\begin{array}{l}\text { Windermere, Cumbria, England; } \\
\text { 1976; reisolation of CCAP } 1403 / 13 B\end{array}$ \\
\hline Anabaena flos-aquae & CCAP $1403 / 13 G$ & $\begin{array}{l}\text { Windermere, Cumbria, England; } \\
1976 \text {; reisolation of CCAP } 1403 / 13 B\end{array}$ \\
\hline Anabaena flos-aquae & CCAP $1403 / 13 \mathrm{H}$ & Windermere, Cumbria, England; 1964 \\
\hline Anabaena flos-aquae $\dagger$ & CCAP $1446 / 1 C$ & Unknown \\
\hline Nostoc ellipsosporum & CCAP $1453 / 2$ & Freshwater ditch, Utrecht, Netherlands \\
\hline Nostoc ellipsosporum & CCAP $1453 / 11$ & Fresh water, Sweden; 1950 \\
\hline Nostoc ellipsosporum & CCAP $1453 / 15$ & Fresh water; USA \\
\hline Nostoc ellipsosporum & CCAP $1453 / 16$ & Fresh water; 1966 \\
\hline Nostoc ellipsosporum & CCAP $1453 / 17$ & Fresh water; 1967 \\
\hline Nostoc ellipsosporum & CCAP $1453 / 18$ & Fresh water, Wisconsin, USA; 1968 \\
\hline Nostoc ellipsosporum & CCAP $1453 / 19$ & Fresh water \\
\hline
\end{tabular}

* Formerly designated A. flos-aquae.

†Formerly designated $A$. inaequalis.

placed at $-20^{\circ} \mathrm{C}$ for at least $20 \mathrm{~min}$. DNA, heavily contaminated by polysaccharide in samples derived from some species, was recovered by centrifugation (microfuge, 13200 r.p.m., $8 \mathrm{~min}$ ) and washed with $70 \%$ ethanol prior to drying of the sample in an airflow cabinet at room temperature and resuspension in TE buffer containing DNase-free RNase A $\left(25 \mu \mathrm{g} \mathrm{ml}^{-1}\right.$; Sigma). DNA recovered by this technique varied from 0.2 to $1 \cdot 2 \mu \mathrm{g}$ per $10 \mathrm{ml}$ of culture. DNA preparations were stored at $-20^{\circ} \mathrm{C}$ and further diluted in TE buffer prior to use in PCR.

DNA concentrations were estimated directly from ethidium bromide fluorescence in agarose gel images against standard quantities of $\lambda$ bacteriophage DNA, either by using a Pharmacia gel documentation system and associated software 
or from scanned images of gel photographs analysed using NIH Image software, version 1.59 , on a Macintosh computer. NIH Image software is available by ftp transfer protocols from Info-mac archives (e.g. ftp://src.doc.ic.ac.uk/ packages/info-mac/) that are mirrored worldwide.

PCR conditions. PCR reactions were either run as $50 \mu \mathrm{l}$ volumes in $300 \mu \mathrm{l}$ thin-walled PCR tubes (Perkin Elmer) or $25 \mu \mathrm{l}$ volumes in 96-tube plates (skirted Thermo-Fast 96) sealed with Thermo-Seal (heat-sealing foil) using a Combi Thermo-Sealer (Advanced Biotechnologies). Reactions normally contained approximately $20-30 \mathrm{pg}$ DNA template (samples shown in Fig. 3 contained up to 3 ng DNA template), one primer $(0.6 \mu \mathrm{M})$, deoxynucleoside triphosphate mixture (40 nM each), 1.0 unit Taq DNA polymerase (Gibco-BRL) or other heat-stable DNA polymerase, one-tenth volume of the appropriate $10 \times$ buffer supplied by the manufacturer, supplemented where appropriate to give a final $\mathrm{MgCl}_{2}$ concentration of $2.0 \mathrm{mM}$, in a total volume of $50 \mu \mathrm{l}$, or half these amounts in $25 \mu$ volumes.

Reactions were cycled on an Ericomp DeltaCycler II thermal cycler using a temperature profile of one cycle of $95^{\circ} \mathrm{C}, 5 \mathrm{~min}$; 30 cycles of $95^{\circ} \mathrm{C}, 30 \mathrm{~s} ; 30^{\circ} \mathrm{C}, 30 \mathrm{~s} ; 72^{\circ} \mathrm{C}, 60 \mathrm{~s}$; one cycle of $72{ }^{\circ} \mathrm{C}, 5 \mathrm{~min}$.

There are 16 possible variants of primers based on the Hip1 sequence GCGATCGC and containing two additional nucleotides at the $3^{\prime}$ end. Four of the 16 possible primers were chosen arbitrarily and used for this study: HipCA (GCGATCGCCA), HipAT (GCGATCGCAT), HipTG (GCGATCGCTG) and HipGC (GCGATCGCGC). The fifth primer used in this study, HipTC (GCGATCGCTC), corresponds to a sequence that is found upstream of nifH genes and other genes transcribed during heterocyst development in Anabaena species (Beesley et al., 1994). PCR products were separated by agarose gel electrophoresis in TBE buffer according to standard protocols (Sambrook et al., 1989) by loading 2-10 $\mu \mathrm{l}$ of the reaction mixture mixed with loading buffer onto an agarose gel containing $1.5 \%(\mathrm{w} / \mathrm{v})$ agarose (NBL Gene Sciences) and $1.5 \%(\mathrm{w} / \mathrm{v}) \mathrm{NuSieve} 3: 1$ (FMC Bioproducts). In some instances (Fig. 3) a deliberate overloading of the gel is shown in order that minor products (light bands) are visible. Typically a loading of $2-3 \mu$ l of reaction mixture was sufficient to show banding patterns suitable for typing. All the extended Hip1 PCR profiles shown were repeated at least five times.

The method of Lu et al. (1997) was used to provide an alternative means of characterizing the Anabaena flos-aquae and Nostoc ellipsosporum isolates. This technique employs PCR to amplify products from the $16 \mathrm{~S}-23 \mathrm{~S}$ rDNA using the primer pairs R1/R18, R14/R18 or R17/R18, as described by Wilmotte et al. (1993). R1/R18-primed PCR amplifies the 16S rDNA, the internal transcribed spacer (ITS) region, $\mathrm{tDNA}^{\text {lle }}$, or tDNA ${ }^{\text {lle }}$ and $\mathrm{tDNA}^{\mathrm{Ala}}$, and the $5^{\prime}$ end of $23 \mathrm{~S}$ rDNA. R14/R18-primed PCR amplifies the same rDNA region, but starting from the $3^{\prime}$ end of $16 S$ rDNA. R17/R18-primed PCR amplifies part of the ITS region, starting at tDNA ${ }^{\text {Ile }}$. Products formed in R17/R18-primed PCR were analysed for restriction polymorphisms using the restriction endonucleases Hinfl, $D d e I$ and $A l u I$, identified as discriminating cyanobacterial species by Lu et al. (1997). The rDNA PCR and RFLP analysis was repeated three times.

The results presented were scanned from the photographic images obtained from a Pharmacia gel documentation system (Pharmacia Biotech) and the digitized images were inverted, corrected for brightness and contrast, and labelled using Adobe Photoshop version 2.5 prior to printing. The size of
PCR products was determined using software associated with the gel documentation system and a 123 bp ladder DNA standard (Gibco-BRL).

\section{RESULTS}

\section{Optimization of the extended Hip1 PCR}

The template DNA preparation procedure used for extended Hip1 typing yields relatively small quantities of impure DNA, but was adopted for the attributes of simplicity, rapidity and general application to diverse cyanobacterial species. To assess whether this crude method allowed reproducible PCR, cultures of Anabaena ATCC 27892 were grown and extracted separately. No significant difference was observed in products obtained by extended Hip1 PCR from these templates (Fig. 1a). Extended Hip1 PCR was achieved directly from cultures concentrated 10 -fold, resuspended in TE buffer and $3 \mu \mathrm{l}$ used in place of template DNA. Rasmussen \& Svenning (1998) achieved PCR using an STRR primer from cyanobacterial cells (filaments). However, in this study both the productivity and the reproducibility of the Hip1 PCR reaction, particularly in formation of larger PCR products, was decreased when whole-cell suspensions were employed instead of a DNA template. This may be a consequence of the different PCR conditions employed.

Concentration of template. The concentration of DNA template that was required for extended Hip1 PCR was determined empirically. Most DNA preparations adequately supported the PCR reaction at a concentration of $20 \mathrm{pg}$ per $50 \mu \mathrm{l}$ reaction (Fig. 1b), but others, notably those from species in which substantial polysaccharide contamination was apparent, required up to $3 \mathrm{ng}$ per $50 \mu \mathrm{l}$ reaction to achieve good productivity, presumably due to some inhibition of the PCR reaction. However $3 \mathrm{ng}$ quantities are not excessive. Various quantities of cyanobacterial templates have been employed in PCR reactions reported in the literature; for example, $100 \mathrm{ng}$ (Lu et al., 1997), $50 \mathrm{ng}$ (Nelissen et al., 1994; Rasmussen \& Svenning, 1998), $10 \mathrm{ng}$ (Bolch et al., 1996) and $5 \mathrm{ng}$ (Wilmotte et al., 1994) of template DNA per reaction.

Reaction with contaminant bacteria. To assess the effect of bacterial contamination, DNA preparations of purified fresh water coliform and streptococcal isolates were used in extended Hip1 PCR and were shown to form products (Fig. 1c).

Concentration of primer. Primer concentration was determined empirically. Concentrations between 100 and $600 \mathrm{nM}$ did not affect the number of bands obtained, but productivity of the reaction was improved at the higher primer concentration. Primer concentrations above $600 \mathrm{nM}$ and enzyme activities above 2 units per $50 \mu \mathrm{l}$ reaction increased nonspecific background relative to discrete products, the two factors being interdependent (data not shown).

Concentration of $\mathrm{Mg}^{2+}$. The $\mathrm{MgCl}_{2}$ concentration of PCR reactions directly affects product formation through the 
(a)

(b)

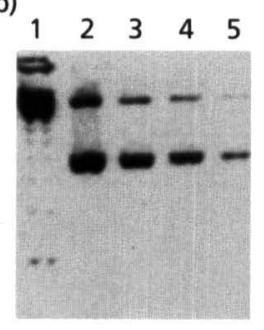

(c)

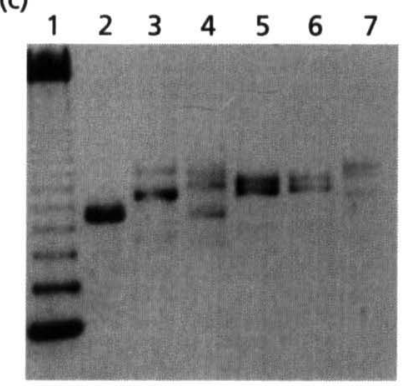

(d)

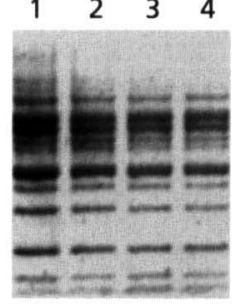

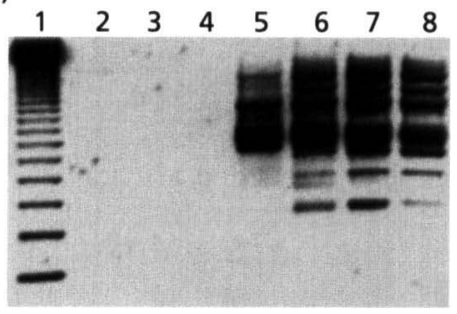

(e)

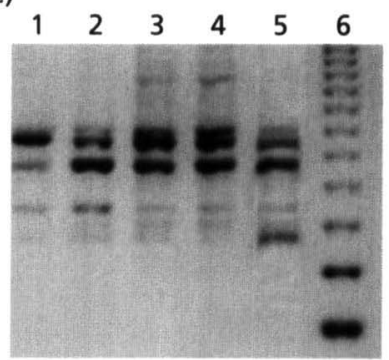

(f)

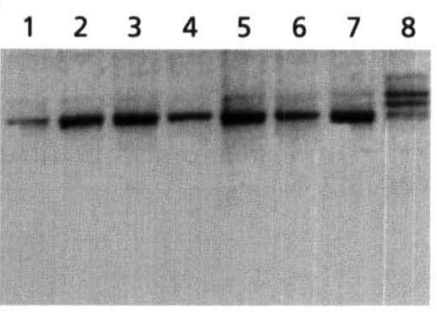

Fig. 1. (a) Assessment of variation due to template preparation. DNA prepared separately from different cultures of Anabaena ATCC 27892 was purified and used as template in a PCR reaction employing HipCA primer. Four examples are shown. (b) Assessment of DNA template concentration. An Anabaena ATCC 27892 DNA template was serially diluted 10fold and $3 \mu \mathrm{l}$ used as template in a PCR reaction employing HipTG primer under standard conditions. Lanes: 1, 123 bp ladder; 2, 3 ng template DNA; 3, $300 \mathrm{pg}$ template DNA; 4, $30 \mathrm{pg}$ template DNA; 5, 3.0 pg template DNA. (c) Hip primer products from freshwater bacterial isolates. A PCR reaction employing DNA templates prepared from coliform (lanes 2 and 3) and streptococcal (lanes 4 to 7) freshwater bacterial isolates and HipTG primer was performed under standard conditions. Lane 1, 123 bp ladder. (d) Effect of varying $\mathrm{Mg}^{2+}$ concentration. A PCR reaction employing an A. cylindrica DNA template and HipCA primer was performed under standard conditions. Lanes: 1,123 bp ladder; $2, \mathrm{no} \mathrm{Mg}^{2+} ; 3$, $0.5 \mathrm{mM} \mathrm{Mg}^{2+} ; 4,1.0 \mathrm{mM} \mathrm{Mg}^{2+} ; 5,1.5 \mathrm{mM} \mathrm{Mg}^{2+} ; 6,2.0 \mathrm{mM} \mathrm{Mg}^{2+} ; 7,2.5 \mathrm{mM} \mathrm{Mg}^{2+} ; 8,3.0 \mathrm{mM} \mathrm{Mg}^{2+}$. (e) Effect of using different DNA polymerase preparations. A PCR reaction employing an A. circularis DNA template and HipTG primer was performed under standard conditions. The DNA polymerase preparations used were: lane 1, Taq polymerase, HT Biotechnologies, UK; lane 2, Taq polymerase, Applied Biotechnologies, UK; lane 3, Taq polymerase, Perkin Elmer, UK; lane 4, Taq polymerase, Gibco-BRL; lane 5, Tbr polymerase, Northumbria Biochemicals, UK; lane 6, 123 bp ladder. (f) Effect of annealing temperature. PCR reactions employing a Nostoc Mac DNA template and HipGC primer were performed under standard conditions, but at different annealing temperatures. Lanes: $1,30^{\circ} \mathrm{C} ; 2,32{ }^{\circ} \mathrm{C} ; 3,34{ }^{\circ} \mathrm{C} ; 4$, $36^{\circ} \mathrm{C} ; 5,38^{\circ} \mathrm{C} ; 6,40^{\circ} \mathrm{C} ; 7,50^{\circ} \mathrm{C} ; 8,60^{\circ} \mathrm{C}$

stringency of primer-template interaction. A minimum of $1.5 \mathrm{mM} \mathrm{MgCl}$ was required to obtain products, but no significant difference was observed in products obtained from reactions containing between 2.0 and $3.0 \mathrm{mM} \mathrm{MgCl}$ (Fig. 1d).

Number of cycles. Although 30 PCR reaction cycles were used in this work, 20 cycles were sufficient to yield ample product with most templates (data not shown). A minimum of $30 \mathrm{~s}$ denaturation was sufficient, but reduction of the extension step below $30 \mathrm{~s}$ decreased productivity of longer products, particularly with some template preparations. Use of a stepped programme in which the time taken to raise the annealing temperature, $30^{\circ} \mathrm{C}$, to the extension temperature, $72^{\circ} \mathrm{C}$, was delayed, in order to encourage extension and stabilization of the short Hip1 primers, yielded products that did not differ in number or quantity from those obtained with the standard profile (data not shown).

Source of polymerase and PCR machine. Variation in PCR typing techniques due to the use of different supplies of
Taq DNA polymerase has been reported (Meunier \& Grimont, 1993). The products formed in extended Hip1primed PCR from cyanobacterial genomic DNA templates did not vary significantly when any of four different Taq polymerase preparations, obtained from different manufacturers, or $\mathrm{Tbr}$ polymerase was used to catalyse the reactions, even when the reactions were constructed with the different manufacturers' buffers and $\mathrm{MgCl}_{2}$ solutions (Fig. 1e). However, it was necessary to compare equivalent enzyme activities per PCR reaction and/or equivalent loading of PCR products on agarose gels. Comparison of different quantities of products may be complicated by low-band-intensity products, which, in extremis, are visible at high loading, but not at low loading. In this limited study, comparison of banding patterns of different intensities could not give rise to confusion between species. Even so, recognition and compensation for low yield in the PCR reaction is recommended. Extended Hip1 PCR yielded the same products when cycling was performed with three different PCR machines (Deltacycler II system, Ericomp; 


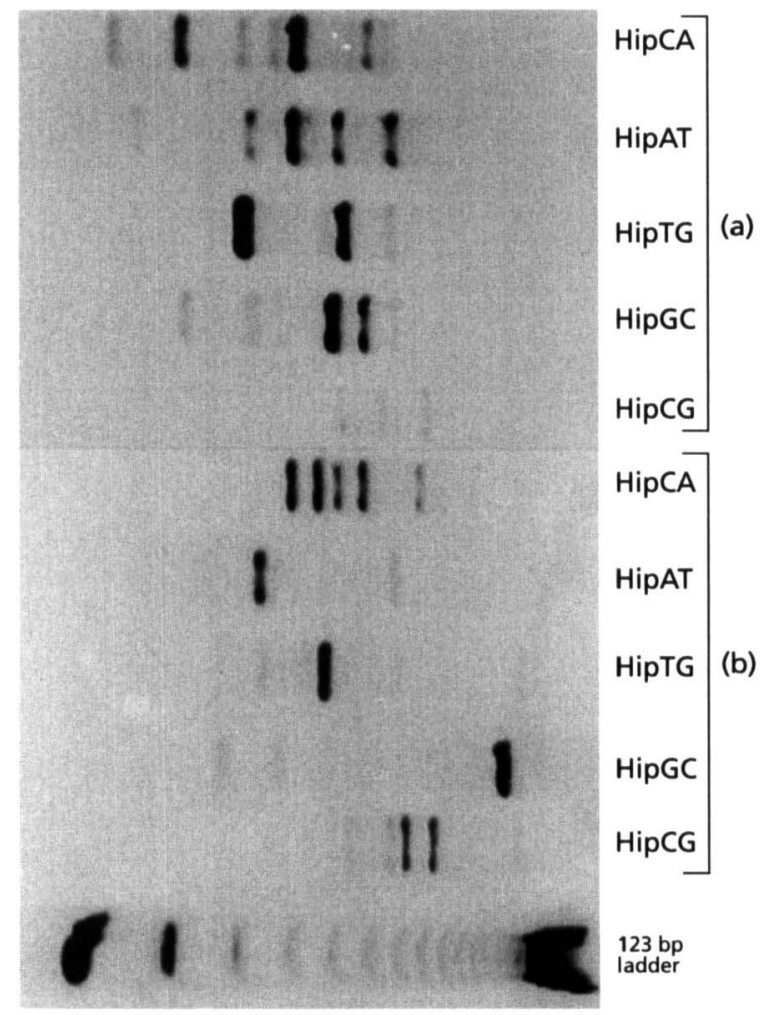

Fig. 2. Comparison of the PCR products formed in reactions primed with different extended Hip1 primers. Template DNA isolated from Anabaena PCC 7120 (a) and A. flos-aquae CCAP 1403/13B (b).

DNA thermal cycler, Perkin Elmer; GeneAmp 2400 PCR system, Perkin Elmer). Nor was variation encountered in the use of PCR tubes or sealed 96-tube plates or due to the position of a tube in a heating block (data not shown).

Annealing temperature. The use of annealing temperatures in the PCR cycle between $30^{\circ} \mathrm{C}$ and $40^{\circ} \mathrm{C}$ did not significantly alter the products obtained with extended Hip1 PCR except that a few products increased or decreased in yield (Fig. 1f). At higher temperatures $\left(50-60^{\circ} \mathrm{C}\right)$ some products were decreased in intensity/ productivity, while other products, which formed lowintensity bands on agarose gel electrophoresis when obtained from low-annealing-temperature PCR $\left(30^{\circ} \mathrm{C}\right)$, increased in productivity and appeared as high-intensity bands on agarose gel electrophoresis.

\section{Comparison of the five primers}

Each of the five extended Hip1 primers reproducibly yielded a distinct set of products when used individually to prime PCR from the same cyanobacterial genomic DNA template (Fig. 2). Each of the five extended Hip1 primers reproducibly yielded a distinct set of products from each of 15 cyanobacterial species tested. Examples of HipTG-, HipGC- and HipCA-primed PCR reactions

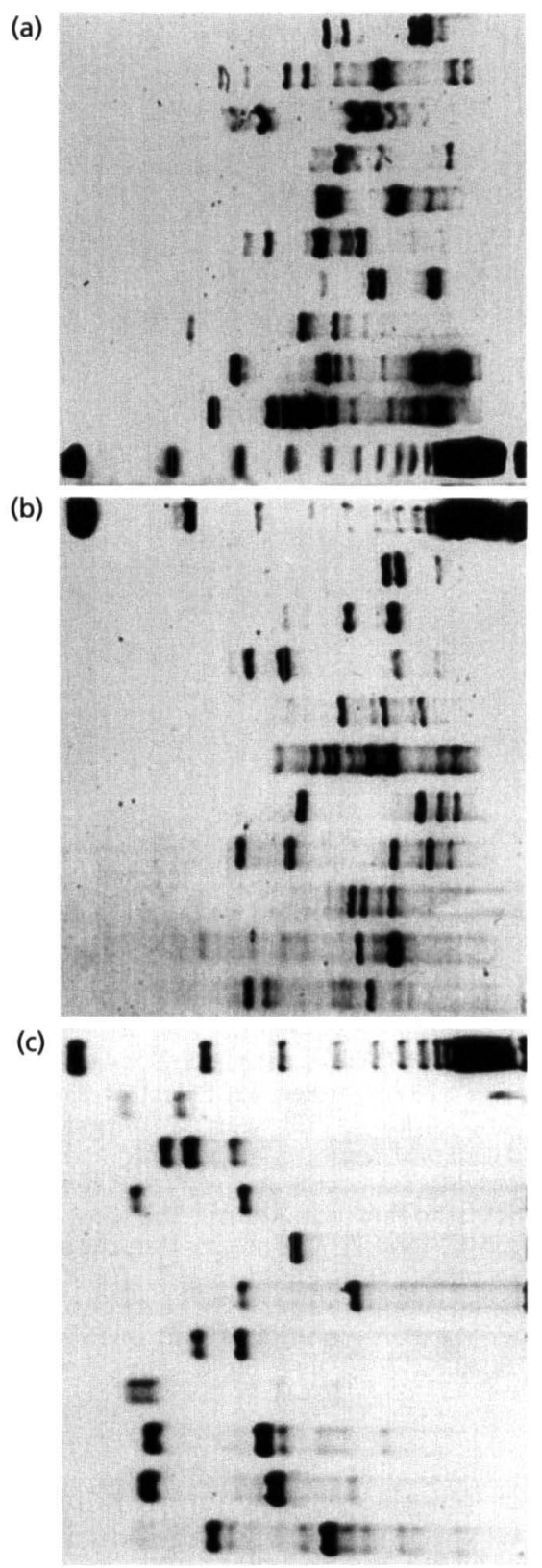

A. cylindrica

O. amoena

N. ellipsosporum

Calothrix sp.

N. flagelliforme

A. circularis

S. muscorum

F. muscicola

Synechocystis sp.

N. muscorum

$123 \mathrm{bp}$

ladder

$123 \mathrm{bp}$

A. cylindrica

O. amoena

N. ellipsosporum

Calothrix sp.

N. flagelliforme

A. circularis

S. muscorum

F. muscicola

Synechocystis sp.

N. muscorum

$123 \mathrm{bp}$
ladder

A. cylindrica

O. amoena

N. ellipsosporum

Calothrix sp.

N. flagelliforme

A. circularis

S. muscorum

F. muscicola

Synechocystis sp.

N. muscorum

Fig. 3. Comparison of the PCR products obtained in extended Hip1 PCR from ten different cyanobacterial DNA templates using HipTG (a), HipGC (b) and HipCA (c).

with ten different cyanobacterial species are shown in Fig. 3.

\section{Resolution of strains within species}

To assess the resolution of subspecies differences afforded by extended Hip1 primer typing, two separate sets of isolates of cyanobacterial species, which have been maintained in the CCAP, were used. These sets of isolates were taken as likely to represent different strains of cyanobacterial species. One set, of eight isolates, originally classified as Anabaena flos-aquae, originated 
(a)

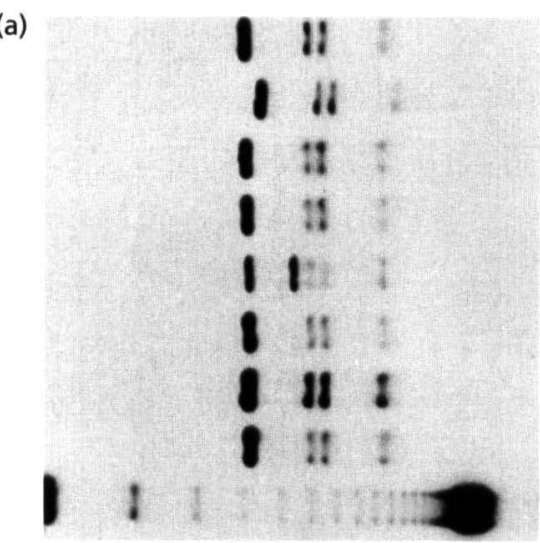

(b)

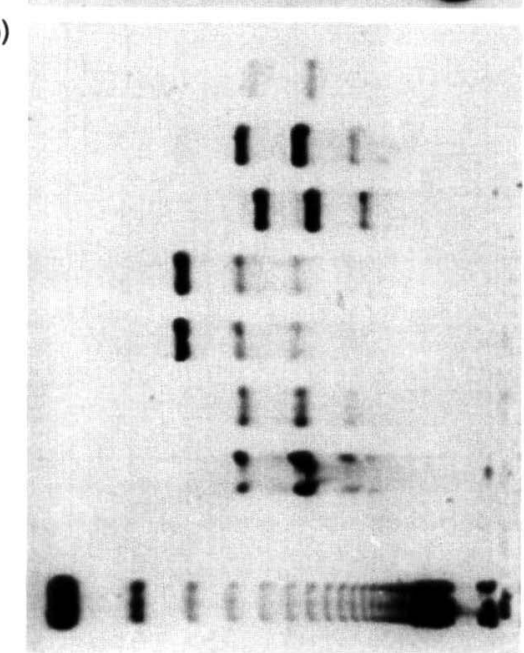

$1403 / 13 \mathrm{H}$

$1446 / 1 C$

$1403 / 13 \mathrm{~A}$

1403/13B

1403/13D

1403/13E

$1403 / 13 \mathrm{~F}$

1403/13G

$123 \mathrm{bp}$
ladder

$1453 / 2$

$1453 / 11$

$1453 / 15$

$1453 / 16$

$1453 / 17$

$1453 / 18$

$1453 / 19$

$123 \mathrm{bp}$

ladder
Fig. 4. Comparison of the R14/R18-primed rDNA PCR products obtained for the A. flos-aquae (a) and $N$. ellipsosporum (b) isolates.

predominantly from UK sources. Isolate CCAP $1403 / 13$ A was originally recorded as $A$. flos-aquae, but has since been reclassified as Anabaena sp. It was included in the experiment as a sample that was likely to be distinct. The other set, of seven isolates classified as Nostoc ellipsosporum, originated from a variety of European and North American sources (Table 2).

The rDNA analysis of the A. flos-aquae isolates showed that isolates CCAP $1403 / 13 \mathrm{~A}$ to $/ 13 \mathrm{H}$ produced similar PCR products and restriction products except that isolate $1403 / 13 \mathrm{D}$ showed an additional product in R14/R18-primed PCR (Fig. 4). Isolate $1446 / 1 C$ was distinct from the other A. flos-aquae isolates (Figs 4 and 5). Hip1 typing confirmed the differences between isolates identified by $\mathrm{rDNA}$ analysis. The CCAP $1403 / 13 \mathrm{~B}, / 13 \mathrm{E}, / 13 \mathrm{~F}, / 13 \mathrm{G}$ and $/ 13 \mathrm{H}$ isolates yielded indistinguishable products by rDNA analysis and in all five extended Hip1-primed PCR reactions. Isolate CCAP $1446 / 1 \mathrm{C}$ was clearly distinguished by both rDNA- and Hip1-primed PCR. Examples of HipCA- and HipATprimed PCR products are shown in Fig. 7. However, although distinguished by an additional product in R14/R18-primed PCR (Fig. 4), CCAP 1403/13D was (a)

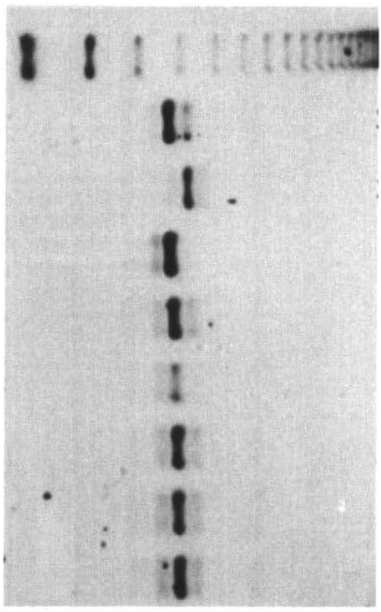

$123 \mathrm{bp}$

$1403 / 13 \mathrm{H}$

$1446 / 1 C$

1403/13A

1403/13B

$1403 / 13 D$

1403/13E

1403/13F

$1403 / 13 G$

(b)

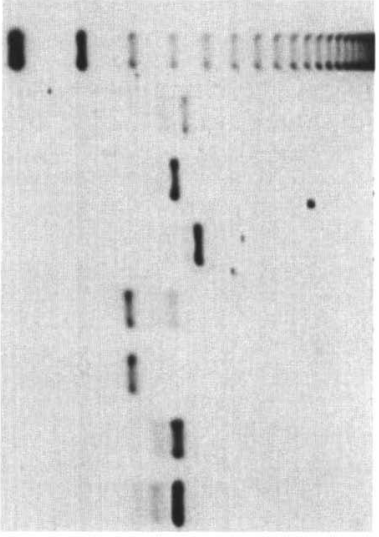

$123 \mathrm{bp}$

ladder

$1453 / 2$

$1453 / 11$

$1453 / 15$

$1453 / 16$

$1453 / 17$

$1453 / 18$

$1453 / 19$

Fig. 5. Comparison of the R17/R18-primed rDNA PCR products obtained for the A. flos-aquae (a) and N. ellipsosporum (b) isolates.

not distinguished by Hip1-primed PCR (Fig. 7). In contrast, isolate CCAP $1403 / 13$ A was clearly distinguished from the majority of CCAP 1403 isolates by Hip1 PCR (Fig. 7), but was distinguished by rDNA analysis only by slightly smaller R17/R18 major PCR product and restriction fragments (Figs 5 and 6).

The rDNA PCR analysis of the seven N. ellipsosporum isolates showed that they were diverse (Figs 4 and 5), in either the size of the PCR products or restriction fragments formed. Extended Hip1-primed PCR also yielded diverse products, confirming the differences between species identified by rDNA analysis; examples of HipCA- and HipAT-primed PCR products are shown in Fig. 8. Major and minor PCR products were observed for both the R14/R18-primed products and the R17/R18-primed products of both sets of isolates (Figs 4 and 5).

\section{DISCUSSION}

The discovery of the Hip1 sequence and its presence in many, though not all, cyanobacteria (Robinson et al., 1995) allowed an assessment of a cyanobacterial typing technique which, akin to the repetitive-sequence- 
(a)

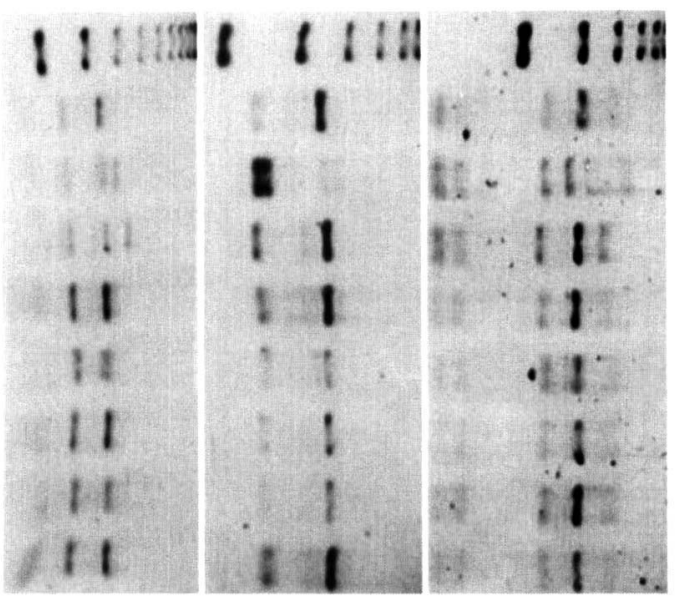

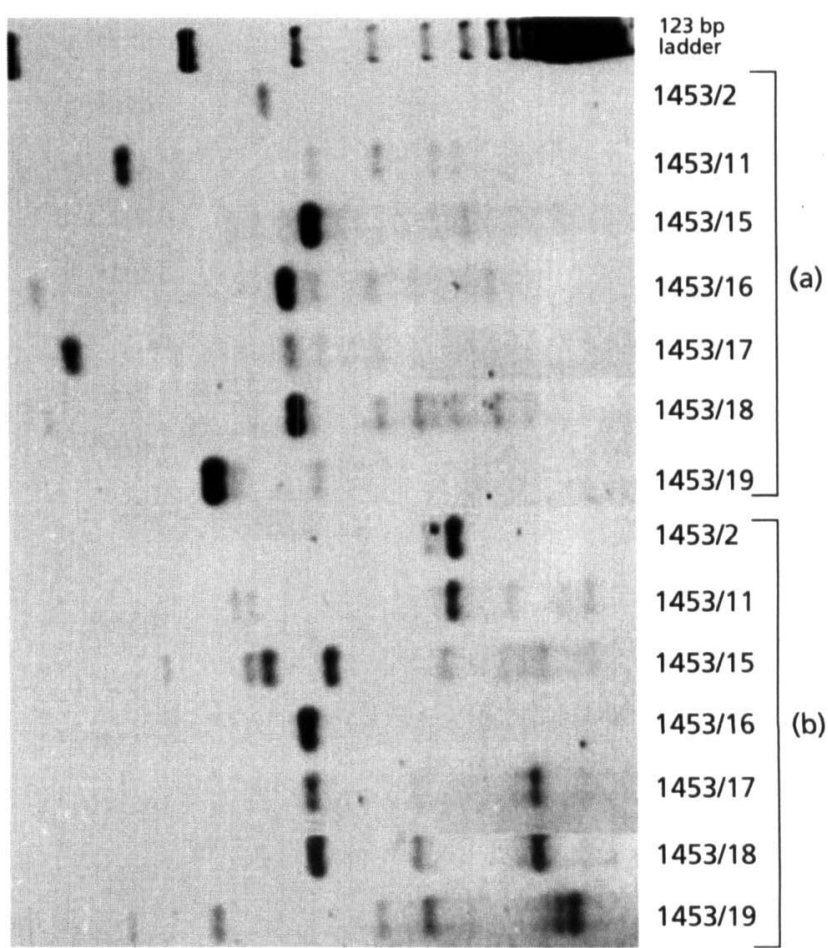

$1403 / 13 \mathrm{H}$

$1446 / 1 C$

$1403 / 13 A$

1403/13B

$1403 / 13 D$

1403/13E

$1403 / 13 F$

1403/13G

$123 \mathrm{bp}$
ladder

(b)

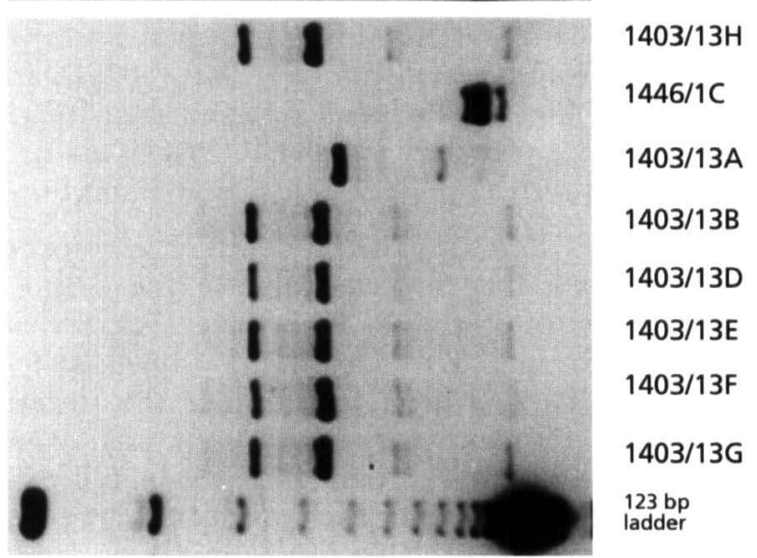

Fig. 7. Extended Hip1-primed PCR products obtained for the $A$. flos-aquae isolates using HipCA primer (a) and HipAT primer (b).

orientated PCR techniques used with bacteria (e.g. Versalovic et al., 1991; Vila et al., 1996) and cyanobacteria (Rasmussen \& Svenning, 1998), is based on the
Fig. 8. Extended Hip1-primed PCR products obtained for the $N$. ellipsosporum isolates using HipCA primer (a) and HipAT primer (b).

amplification of DNA between adjacent repeated Hip1 sequences in the chromosomal DNA of cyanobacteria. However, the frequency of Hip1 repeats in the DNA of some cyanobacteria is high. For example, Robinson $e t$ al. (1995) estimated from analysis of database sequence that the Hip 1 sequence occurred on average every $320 \mathrm{bp}$ in the chromosomal DNA of Synechococcus PCC 6301. Consequently the number of discrete products obtained in a Hip1-primed PCR reaction is very large and not conducive to distinguishing species by a simple comparison of agarose gel electrophoresis patterns. To decrease the number of PCR products obtained and therefore provide a clearer and more distinctive banding pattern, primers were constructed in which two additional bases were added to the $3^{\prime}$ end of the Hip1 sequence.

DNA polymerases extend the $3^{\prime}$ end of primers. Since the complementarity of the $3^{\prime}$ end of the primer with the template dictates efficient extension and PCR product formation, extending the $3^{\prime}$ end of the palindromic Hip1 sequence by two nucleotides should restrict efficient priming to those genomic Hip1 sequences in which the flanking sequences complement the two nucleotide extension. This strategy was successful, as shown by the different PCR products obtained from a cyanobacterial genomic DNA template with each of the $5^{\prime}$ extended Hip1 primers that were tested (Fig. 2).

The prime objective of the work was to assess the ability of extended Hip1-primed PCR to clearly distinguish 
species and strains of cyanobacteria. In the three examples shown, ten species of cyanobacteria drawn from a variety of genera were tested and yielded clearly distinct extended Hip1-primed PCR products (Fig. 3). The extended Hip1 primers generated PCR products and agarose gel electrophoresis banding patterns that clearly distinguished all ten species of cyanobacteria. These included the three Nostoc and two Anabaena species that present examples of closely related species occupying the same genera.

One characteristic of the banding patterns on agarose gel electrophoresis obtained from extended Hip1 PCR products is the presence of bands of widely different intensities resulting from the different quantities of products formed (Fig. 3). This variation in productivity was reproducible and was not affected by Taq polymerase activity, $\mathrm{Mg}^{2+}$ concentration or primer concentration. Such variation in the intensity of bands (i.e. productivity of individual products) is a characteristic of RAPD and repetitive-sequence PCR as shown by published data (e.g. for bacteria, Meunier \& Grimont, 1993; Gillings \& Holley, 1997; Mahenthiralingam et al., 1996; and cyanobacteria, Rasmussen \& Svenning, 1998). Experiments showed that some high-intensity products declined in productivity as the PCR annealing temperature was increased, indicating that they resulted from inexact priming from template sites that were not completely complementary to the primer (Fig. 1f). Consequently inexact priming does not provide a simple explanation for the formation of low-intensity products. Other low-intensity products increased in productivity as the annealing temperature increased. This would be consistent with the hypothesis that intramolecular template secondary structure occludes some priming sites, reducing productivity of some Hip1-primed products. Since most typing reactions employ annealing temperatures well below $65^{\circ} \mathrm{C}$, at which template secondary structure is minimized, occlusion of primer sites by secondary structure may explain the variation in PCR product intensity which is common to PCR typing techniques.

To explore the resolution afforded by extended Hip1 PCR, two sets of isolates present in the CCAP collection (Tables 1 and 2) were analysed. The Hip1 analysis compared favourably with the rDNA analysis in discriminating similar and distinct strains. Both techniques found the A. flos-aquae strains to be similar and the $N$. ellipsosporum strains to be more diverse. However, the two techniques differ in their discrimination of isolates CCAP 1403/13A and /13D. Clearly there exists an element of chance as to whether a chosen technique will distinguish particular strains and it would be unwise to rely upon the results of a single technique as evidence that two isolates are identical.

The products obtained from R1/R18-primed (data not shown) and R14/R18-primed (Fig. 4) PCR contained minor products as reported by Lu et al. (1997). These minor products were ascribed by Lu et al. (1997) to heterogeneity for heterocyst differentiation or the formation of heteroduplexes containing conserved $3^{\prime}$ and $5^{\prime}$ ends, but highly variable ITS sequences. Minor products were also present in R17/R18-primed rDNA PCR (Fig. $5)$. Such minor products were not reported by Lu et al. (1997). In addition to the explanations suggested by $\mathrm{Lu}$ et al. (1997) for minor products, they may also be attributed to a template at low concentration, e.g. a contaminating bacterial DNA-although the R18 primer discriminates against bacterial rDNA amplification (Lu et al., 1997; Nelissen et al., 1996) - or rare cyanobacterial rDNA cistrons that retain the R17 primer site within the tDNA ${ }^{\text {Ile }}$ gene, but are of a different structure within the $3^{\prime}$ end of the ITS region. Alternatively they may represent poor amplification of products primed from sites outside the rRNA cistrons. RFLP analysis of R17/R18-primed PCR products was complicated by the presence of the minor products, but the restriction fragments obtained for the A. flos-aquae isolates were similar to those described by Lu et al. (1997) for the A. flos- aquae isolate included in their survey.

Extended Hip1 PCR appears from this initial study to be robust, contain less inherent variability than reported for other PCR typing systems (Meunier \& Grimont, 1993) and be applicable to a wide range of cyanobacterial species and strains. Hip1 PCR produces products with bacterial templates (Fig. 1c). While fewer than those normally found with cyanobacterial templates, this necessitates the purificiation of cyanobacterial isolates prior to PCR typing. Use of different enzyme activities per PCR reaction and/or comparison of different loads on agarose gels were identified as potential sources of confusion, particularly where less intense bands (low-productivity products) are included. As with other enzyme-based assays, a consistent and uniform construction of the assay and analysis of products is required, with recognition of and compensation for poor amplification of products.

The CCAP database contains information describing the A. flos-aquae and N. ellipsosporum isolates used in this study (compiled in Table 2). The six related strains of A. flos-aquae all originated from UK sources (Lake Windermere and Wales) over a period of 12 years. The two distinct strains are probably of American origin. Note that CCAP $1446 / 1 \mathrm{C}$ was originally designated Anabaena inaequalis and later reclassified as A. flosaquae. CCAP 1403/13A, originally designated A. flosaquae, has been reclassified as Anabaena sp. (Tompkins et al., 1995). The N. ellipsosporum isolates, which appear to be more diverse than the A. flos-aquae group, have a more varied geographical origin. The number of isolates tested is small, but would suggest that strain variation is an aspect of major geographical location and that ecotypes within a region are more closely related.

Five of the 16 possible Hip1 extended primers have been shown to produce different PCR products (Figs 2 and 3 ) for each species of cyanobacterium studied and to distinguish cyanobacterial strains (Figs 7 and 8). One advantage of Hip 1 typing is the degree of resolution that is afforded by possible use of all 16 extended Hip1 
primers. Even so, as with other PCR-based techniques, the need to assume that size of product is an indicator of identical products, and the relatively low information content of the data, detract from the use of extended Hip1 PCR for phylogenetic studies. Extended Hip1 PCR typing may be of use in distinguishing cyanobacterial strains and species where a large number of samples are involved, e.g. the enumeration of purified isolates from environmental samples, in the maintenance of stock cultures or as a preliminary assay to distinguish between multiple strains prior to rDNA sequence analysis.

\section{ACKNOWLEDGEMENTS}

We thank the Leverhulme Trust, who supported this work under grant number $\mathrm{F} / 185 / \mathrm{W}$. We also wish to thank $\mathrm{N}$. and P. Robinson (Newcastle upon Tyne University, UK) for kindly providing a sample of Hip1 primer and a Calothrix D253 DNA sample, and P. Bisen (Barkatullah University, India) and P. Rowell (Dundee University, UK) for providing cultures.

\section{REFERENCES}

Allen, M. B. \& Arnon, D. I. (1955). Studies on nitrogen-fixing blue green algae. I. Growth and nitrogen fixation by Anabaena cylindrica Lemm. Plant Physiol 30, 366-372.

Arbeit, R. D., Authur, M., Dunn, R. D., Kim, C., Selander, R. K. \& Goldstein, R. (1990). Resolution of recent evolutionary divergence among Escherichia coli from related lineages: the application of pulsed field gel electrophoresis to molecular epidemiology. $J$ Infect Dis 161, 230-235.

Beesley, B. E., Smith, R. J., Temple, S. J. \& Lea, P. J. (1994). Cloning and nucleotide sequence of the gene encoding dinitrogenase reductase $(n i f \mathrm{H})$ from the cyanobacterium Nostoc 6720. Biochim Biophys Acta 1219, 548-550.

Bolch, C. J. S., Blackburn, S. I., Neilan, B. A. \& Grewe, P. M. (1996). Genetic characterisation of strains of cyanobacteria using PCRRFLP of the $c p c B A$ intergenic spacer and flanking regions. J Phycol 32, 445-451.

Britschgi, T. B. \& Giovannoni, S. J. (1991). Phylogenetic analysis of a natural marine bacterioplankton population by ribosomal RNA gene cloning and sequencing. Appl Environ Microbiol 57, $1707-1713$

Castenholz, R. W., Manhart, J. R., Mccourt, R. M., Wood, A. M. \& Leatham, T. (1992). Species usage, concept, and evolution in the cyanobacteria (blue-green algae). J Phycol 28, 737-745.

Doers, M. P. \& Parker, D. L. (1988). Properties of Microcystis aeruginosa and $M$. flos-aquae (Cyanophyta) in culture: taxonomic implicatons. J Phycol 24, 502-508.

Evans, E. H., Foulds, I. \& Carr, N. G. (1976). Environmental conditions and morphological variation in the blue green alga Chloroglea fritschii. J Gen Microbiol 92, 147-155.

Ferris, M. J., Muyzer, G. \& Ward, D. M. (1996). Denaturing gradient gel electrophoresis profiles of $16 \mathrm{~S}$ ribosomal RNA defined populations inhabiting a hot-spring microbial mat community. Appl Environ Microbiol 62, 340-346.

Frey, P., Smith, J. J., Albar, L., Prior, P., Saddler, G. S., Trigaletdemery, D. \& Trigalet, A. (1996). Bacteriocin typing of Burkbolderia (Pseudomonas) solanacearum race-1 of the French West Indies and correlation with the genomic variation of the pathogen. Appl Environ Microbiol 62, 473-479.

Fuhrman, J. A., McCallum, J. A. \& Davis, A. A. (1993). Phylogenetic diversity of subsurface marine microbial communities. Appl Environ Microbiol 59, 1294-1302.

Georghiou, P. R., Hamill, R. J., Wright, C. E., Versalovic, J., Koeuth, T., Watson, D. A. \& Lupski, J. R. (1995). Molecular epidemiology of infections due to Enterobacter aerogenes: identification of hospital outbreak-associated strains by molecular techniques. Clin Infect Dis 20, 84-94.

Giesendorf, B. A. J., Van Belkum, A., Koeken, A., Stegeman, H., Henkens, M. H. C., Van der Plas, J., Goosens, H., Neisters, H. G. M. \& Quint, W. G. V. (1993). Development of species specific DNA probes for Campylobacter jejuni, Campylobacter coli and Campylobacter lari by polymerase chain reaction fingerprinting. J Clin Microbiol 31, 1541-1546.

Gillings, M. \& Holley, M. (1997). Repetitive element PCR fingerprinting (rep-PCR) using enterobacterial repetitive intergenic consensus (ERIC) primers is not necessarily directed at ERIC primers. Lett Appl Microbiol 25, 17-21.

Gupta, A., Morby, A. P., Turner, J. S., Whitton, B. A. \& Robinson, N. J. (1993). Deletion within the metallothionein locus of cadmium tolerant Synechococcus PCC6301 involving a highly iterated palindrome (Hip1). Mol Microbiol 7, 189-195.

Hulton, C. S. J., Higgins, C. F. \& Sharp, P. M. (1991). ERIC sequences - a novel family of repetitive elements in the genomes of Escherichia coli, Salmonella typhimurium, and other enterobacteria. Mol Microbiol 5, 825-834.

Le-Bourgeois, P., Lautier, M., Mata, M., Ritzenthaler, P. \& LeBourgeois, P. (1993). Chromosome mapping in lactic acid bacteria. FEMS Microbiol Rev 12, 109-124.

Lipman, L. J. A., Denijs, A., Lam, T. J. G. M., Rost, J. A., Vandijk, L. S., Chukken, Y. H. \& Gaastra, W. (1996). Genotyping by PCR, of Stapbylococcus aureus strains isolated from mammary glands of cows. Vet Microbiol 38, 51-55.

Lotti, F., Giovannetti, L., Margheri, M. C., Ventura, S. \& Materassi, R. (1996). Diversity of DNA methylation pattern and total DNA restriction pattern in symbiotic Nostoc. World J Microbiol Biotechnol 12, 38-42.

Lu, W., Evans, E. H., McColl, S. M. \& Saunders, V. A. (1997). Identification of cyanobacteria by polymorphisms of PCRamplified ribosomal DNA spacer region. FEMS Microbiol Lett 153, 141-149.

Mahenthiralingam, E., Campbell, M. E., Foster, J., Lam, J. S. \& Speert, D. P. (1996). Random Amplified Polymorphic DNA typing of Pseudomonas aeruginosa isolates recovered from patients with cystic fibrosis. J Clin Microbiol 34, 1129-1135.

Mazel, D., Houmard, J., Castets, M. \& Tandeau de Marsac, N. (1990). Highly repetitive DNA sequences in cyanobacterial genomes. J Bacteriol 172, 2755-2761.

Meunier, J. R. \& Grimont, P. A. D. (1993). Factors affecting reproducibility of random amplified polymorphic DNA fingerprinting. Res Microbiol 144, 373-379.

Mullins, T. D., Britschgi, T. B., Krest, R. L. \& Giovanni, S. J. (1995). General comparisons reveal the same unknown bacterial lineages in Atlantic and Pacific bacterioplankton communities. Limnol Oceanogr 40, 148-158.

Neilan, B. A. (1996). Identification and phylogenetic analysis of toxigenic cyanobacteria by multiplex randomly amplified polymorphic DNA PCR. Appl Environ Microbiol 61, 2286-2291.

Neilan, B. A., Jacobs, D. \& Goodman, A. E. (1995). Genetic diversity and phylogeny of cyanobacteria determined by DNA polymorphisms within the phycocyanin locus. Appl Environ Microbiol 61, 3875-3883.

Nelissen, B., Wilmotte, A., Neefs, J. M. \& De Wachter, R. (1994). 
Phylogenetic relationships among filamentous helical cyanobacteria investigated on the basis of $16 \mathrm{~S}$ ribosomal RNA gene sequence analysis. Syst Appl Microbiol 17, 206-210.

Nelissen, B., De Baere, R., Wilmotte, A. \& De Wachter, R. (1996). Phylogenetic relationships of nonaxenic filamentous cyanobacterial strains based on $16 \mathrm{~S}$ rRNA sequence analysis. $J \mathrm{Mol}$ Evol 42, 194-200.

Rasmussen, U. \& Svenning, M. M. (1998). Fingerprinting of cyanobacteria based on PCR with primers derived from short and long tandemly repeated repetitive sequences. Appl Environ Microbiol 64, 265-272.

Rippka, R. (1988). Recognition and identification of cyanobacteria. Methods Enzymol 167, 3-67.

Robinson, N. J., Robinson, P. J., Gupta, A., Bleasby, A. J., Whitton, B. A. \& Morby, A. P. (1995). Singular overrepresentation of an octameric palindrome, Hip1, in DNA from many cyanobacteria. Nucleic Acids Res 23, 729-735.

Rouhiainen, L., Sivonen, K., Buikema, W. J. \& Haselkorn, R. (1995). Characterisation of toxin-producing cyanobacteria by using an oligonucleotide probe containing a tandemly repeated heptamer. J Bacteriol 177, 6021-6026.

Sambrook, J., Fritsch, E. F. \& Maniatis, T. E. (1989). Molecular Cloning: a Laboratory Manual, 2nd edn. Cold Spring Harbor, NY: Cold Spring Harbor Laboratory.

Schmidt, T. M., Delong, E. F. \& Pace, N. R. (1991). Analysis of a marine picoplankton community by $16 \mathrm{~S}$ ribosomal RNA gene cloning and sequencing. J Bacteriol 73, 4371-4378.

Stull, T. L., LiPuma, J. J. \& Edlind, T. D. (1988). A broad-spectrum probe for molecular epidemiology of bacteria : ribosomal RNA. J Infect Dis 157, 280-286.
Tenover, F. C., Arbeit, R. D., Goering, R. V., Mickelsen, P. A. Murray, B. E., Pershing, D. H. \& Swaminathan, B. (1995). Interpreting chromosomal DNA restriction patterns produced by pulsed field gel electrophoresis : criteria for bacterial strain typing. J Clin Microbiol 33, 2233-2239.

Tompkins, J., DeVille, M. M., Day, J. G. \& Turner M. F. (1995). Culture Collection of Algae and Protozoa, Catalogue of Strains. Ambleside, Cumbria, UK: Culture Collection of Algae and Protozoa.

Versalovic, J., Koeuth, T. \& Lupski, J. R. (1991). Distribution of repetitive DNA sequences in Eubacteria and application to fingerprinting of bacterial genomes. Nucleic Acids Res 19, 6823-6831.

Vila, J., Marcos, M. A. \& Jimemez de Anta, M. T. (1996). A comparative study of different PCR-based DNA fingerprinting techniques for typing of the Acinetobacter calcoaceticus-A. baumannii complex. J Med Microbiol 44, 482-489.

Welsh, J. \& McClelland, M. (1990). Fingerprinting genomes using PCR with arbitrary primers. Nucleic Acids Res 18, 7213-7218.

Wilmotte, A., Van der Auwera, G. \& De Wachter, R. (1993). Structure of the $16 \mathrm{~S}$ ribosomal RNA of the thermophilic cyanobacterium Chlorogloeopsis HTF ("Mastigocladus lamino-

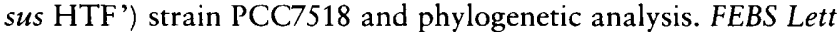
317, 96-100.

Wilmotte, A., Neefs, J. M. \& De Watcher, R. (1994). Evolutionary affiliation of the marine nitrogen-fixing cyanobacterium Trichodesmium sp. strain NIBB 1067 , derived by $16 \mathrm{~S}$ ribosomal RNA analysis. Microbiology 140, 2159-2164.

Received 2 April 1998; revised 15 May 1998; accepted 22 June 1998. 